\title{
Analysis of labour risks in the Spanish industrial aerospace sector
}

\author{
JUAN LAGUARDIA ${ }^{1}$, EMILIO RUBIO ${ }^{2}$, ANA GARCIA ${ }^{2}$ and RAFAEL GARCIA-FONCILLAS ${ }^{2}$ \\ ${ }^{1}$ SP/MDEF/EA, UMAAD-ZARAGOZA, B.A. de Zaragoza, Ctra Aeropuerto, 50071, Zaragoza, España \\ 2 Department of Microbiology, UNIZAR, Preventive Medicine and Public \\ Health, C/ Domingo Miral s/n, 50009 Zaragoza, España
}

Manuscript received on September 5, 2016; accepted for publication on June 3, 2016

\begin{abstract}
Labour risk prevention is an activity integrated within Safety and Hygiene at Work in Spain. In 2003, the Electronic Declaration for Accidents at Work, Delt@ (DELTA) was introduced. The industrial aerospace sector is subject to various risks. Our objective is to analyse the Spanish Industrial Aerospace Sector (SIAS) using the ACSOM methodology to assess its labour risks and to prioritise preventive actions. The SIAS and the Services Subsector (SS) were created and the relevant accident rate data were obtained. The ACSOM method was applied through double contrast (deviation and translocation) of the SIAS or SS risk polygon with the considered pattern, accidents from all sectors (ACSOM G) or the SIAS. A list of risks was obtained, ordered by action phases. In the SIAS vs. ACSOM G analysis, radiation risks were the worst, followed by overstrains. Accidents caused by living beings were also significant in the SS vs. SIAE, which will be able to be used to improve Risk Prevention. Radiation is the most significant risk in the SIAS and the SS. Preventive actions will be primary and secondary. ACSOM has shown itself to be a valid tool for the analysis of labour risks.
\end{abstract}

Key words: ACSOM, labour risks, workplace prevention, aerospace industrial sector.

\section{INTRODUCTION}

For many years, accidents in the workplace were considered an inevitable consequence of work. In the 19th century a series of active policies was introduced to protect workers. Initially this protection was aimed at the most vulnerable of workers, children, as reflected in legislation passed in the United Kingdom (The Factory Act 1833, Lee WR 1973) and France (Gaumy and Protea 1982). In the same century, Prussia introduced factory inspections by doctors.

Correspondence to: Juan Laguardia

E-mail: jlagchu@ea.mde.es
The year 1900 marked the introduction of the first Spanish Labour Accidents Law, to which new regulations have since been progressively added. The Health and Safety Act of 1995 represented a milestone. The addition of the Electronic Declaration of Accidents at Work, (Delt@) in 2003, led to the creation of a database (DELTA), which has allowed more precise epidemiological studies to be carried out, given the greater capacity for statistical analysis.

The 2009 National Classification of Economic Activities (CNAE 2009) was approved by Royal Decree 475/2007 of 13th April. The CNAE assigns a four-digit code to each economic activity that can 
be carried out, and allows the selection of codes relating to all economic activities that comprise a given economic sector.

Conte et al. (2007a) developed a theory of accidents in populations, in which the conceptual considerations of accidents in the workplace point towards non-deterministic phenomena, breaking with the Domino Theory of Heinrich (Melia et al. 1998). This theory considers accidents as dynamic events composed of risks and injuries that, when represented in a contingency table, can be studied mathematically. The theory posits that events can be explained after their occurrence. Accordingly, accident rates represent the frequency with which an accident occurs.

A new paradigm, the Accident Soma (ACSOM), arose from this conceptual basis (Conte 2004, Conte et al. 2005, 2011a, Conte and Rubio 2006). This method is based on two hypotheses: the first concerns infection schemes (the probability of suffering an accident is higher in populations that have suffered one before), while the second concerns an empirical application of the law of large numbers (very rare events occur very rarely).

Using a historical record of accidents (Chiara et al. 2009), the objective of ACSOM is to identify the real risk and determine the criteria required for their assessment and prioritisation (Conte et al. 2011a, b), thus allowing preventative actions to be formulated.

A risk-injury binomial is identified for each recorded accident. The list of risks and injuries identified by the International Labour Organisation (ILO) and the area codes for Spain are published in Ministerial Order of 16-12-1987 and are divided into 19 categories each, resulting in the risk-injury $(\mathrm{R} \times \mathrm{I})$ matrix $(19 \times 19)$ used by ACSOM.

The ACSOM method is thus based on the processing of the $\mathrm{R} \times \mathrm{I}$ matrix using statistical techniques (segmentation, multidimensional scaling, factorial analysis, correspondence analysis, cluster analysis and comparison of proportions)
(Conte and Rubio 2005, Conte et al. 2007b, 2011a, b, García et al. 2009). The ACSOM of a country, region, branch of activity, or business will thus be based on the data that comprise the $\mathrm{R} \times \mathrm{L}$ matrix, (García et al. 2009, Rubio et al. 2012). ACSOM G (ACSOM General) is defined as the highest level ACSOM (record of accident rates of the general population of the study) which will later be used as a reference pattern.

A bespoke computer programme, BIOIN (developed specifically for use with the ACSOM method), translates the data from the DELTA or ILO databases, runs comparisons with the aforementioned pattern, and produces the corresponding report (Rubio et al. 2008a, b).

By extrapolating the analysis to any causeconsequence relationship we can obtain individual, specific "ACSOMs" for the areas analysed. The use of the ACSOM method to analyse complications that arise during anaesthesiology and resuscitation (Rubio García et al. 2013) and its inclusion in analytical studies of the seriousness of risks and injuries associated with the accident rate of the Spanish working population (Adesanya et al. 2014) represent new applications of the ACSOM paradigm. Analysis of the seriousness of risks and injuries is performed based on the number of days leave associated with each registered accident.

In Spain, the birth of the aerospace industry was firmly linked to the metallurgical industry, specifically the automotive sector, as exemplified by "Talleres Hereter" and Hispano Suiza (Utrilla 2007) and the railroad sector, the best example of which is the Escoriaza workshops of Zaragoza (Barragán 2005).

Since then, aviation and industry have been closely linked and, as a consequence, the former has shared the risks of the latter. Aviation is also exposed to the generic risks of commercial activity and management, as well as the specific risks associated with flying activities, both "inside" and "outside" the atmosphere (Garcia and Gartman 1998, Patterson and Rayman 1998). 
New industrial processes, the addition of new structural materials (Pellet 2001, Brocal 2012), the use of new chemical compounds, highly resistant but demonstrably toxic metal alloys (Falcy 2010), electrical components and procedures needed to achieve ergonomic stability pose major challenges in terms of the prevention of associated risks. Noise as an etiologic agent is a feature of both inflight and terrestrial activities within the aerospace industry (Normand 2010).

Several authors have highlighted the reduction in the thickness of the atmospheric gas layer and the attendant risk posed by "cosmic" ionising radiation during flight phases (Seigneuric 1991, INSHT NTP-728, Gaona 2010), which has led to most companies classifying air crews as professionally exposed workers (Griffiths and Powell 2012).

The reappearance of forgotten infectious pathologies is a stark reality in developed countries, and is linked to migratory movements and tourism, among other factors (Gestal 1997). Air transport, and by extension aircraft crew, play important roles in both phenomena (legislation exists regarding insect eradication in aircraft cabins) (WHO 2012, Rayman 2006). Passenger attacks on aircraft crews are not a new phenomenon (Rojas and Solano 2007).

Problems associated with carrying out prolonged complex tasks are well documented, particularly in the case of aircraft crews (Lyons and Nace 2007). Connecting risks to injuries in the aeronautic sector, whether associated with specific tasks or not, is a key objective of preventative action. However, even the most exhaustive attempts to achieve this goal are limited to relating risks to injuries in a non-quantitative manner (Briggs 1998, Bourcier 1998). The incorporation of the ACSOM method into the analysis of accident rate (Conte 2004, Conte and Rubio 2005, Conte et al. 2011a, b) overcomes this problem and allows the quantification of risks (Conte et al. 2007b).

This work initiates the study of the aerospace sector, specifically focusing on risks as triggers of accidents. Further studies will address the relationship of risks with specific injuries and the severity thereof.

As such, our aim is to analyse accidents in the aerospace sector using the ACSOM methodology in order to determine the associated specific risks and to prioritise preventative actions.

\section{MATERIALS AND METHODS}

\section{MATERIALS}

Data were obtained from the DELTA database of the Ministry of Employment, provided by the Spanish Institute of Health and Safety at Work. The data were gathered within the first three years of the creation of the database and relate to all declared accidents in the workplace (TAS - Employment and Social Affairs - Order 2926/2002 of 19th November). The date, risk and the Economic Activity Classification code of the company were extracted from the recorded data.

DELTA uses the new nomenclature of the ILO (Ministerial Order of 19-11-2002); Type of Contact and Injury. It was thus essential to translate this data into risks and injuries, respectively (Rubio et al. 2008a). As mentioned above, this is one of the features of the BIOIN programme (Rubio et al. 2012a). The 19 risks and injuries are listed in Table I.

The Spanish Industrial Aerospace Sector (SIAS) was created based on the 2009 National Classification of Economic Activities (CNAE 2009), and consists of three subsectors (Table II). Within the SIAS, the working population that carries out its activity in businesses directly related to transport and education (instruction) is assigned to a subpopulation (or subsector) known as the Services Subsector (SS). The associated activities are known as Services. The SIAS has recorded 64,562 cases of accidents, of which 18,157 relate to the SS. The total number of accidents recorded in DELTA over the same period was 2,585,539 (see Table III). 
TABLE I

The 19 selected Risks and Injuries from the ILO classification.

\begin{tabular}{llll}
\hline & \multicolumn{1}{c}{ CODES OF RISKS } & & \multicolumn{1}{c}{ CODES OF INJURIES } \\
\hline R1 & Falls of persons from a height (at different level) & L1 & Fractures \\
R2 & Slips, trips, falls of persons (at one or same level) & L2 & Luxations \\
R3 & Falls of objects on persons by collapse & L3 & Twists, strains and sprains \\
R4 & Falls of objects on persons by handling & L4 & Back pain (lumbago etc.) \\
R5 & Falls of objects on persons by detachment & L5 & Slipped disk \\
R6 & Treading on objects, piercing, cuts, etc & L6 & Contusions and internal traumatism \\
R7 & Collision with stationary objects & L7 & Amputations and loss of the eyeball \\
R8 & Collision with moving object & $\mathbf{L 8}$ & Other injuries (piercing, cutting, etc.) \\
R9 & Being struck by objects or tools & $\mathbf{L 9}$ & Superficial traumatism \\
R10 & Projections of fragments or particles & $\mathbf{L 1 0}$ & Bruises, contusions and crushing \\
R11 & Entrapment by or between objects & $\mathbf{L 1 1}$ & Objects in the eyes (particles, etc.) \\
R12 & Accidents involving mobile machinery and traffic & $\mathbf{L 1 2}$ & Conjunctivitis \\
R13 & Overstrain & $\mathbf{L 1 3}$ & Poisoning and intoxications \\
R14 & Thermal contact/exposure & $\mathbf{L 1 4}$ & Burns \\
R15 & Exposure to electrical contact & $\mathbf{L 1 5}$ & Environmental hazard \\
R16 & Exposure to chemical substances & $\mathbf{L 1 6}$ & Suffocation \\
R17 & Exposure to radiation & $\mathbf{L 1 7}$ & Electrical effects (shock, etc) \\
R18 & Explosions and fires & $\mathbf{L 1 8}$ & Radiation poisoning \\
R19 & Accidents caused by living beings & $\mathbf{L 1 9}$ & Multiple injuries \\
\hline
\end{tabular}

TABLE II

Creation of the Spanish Industrial Aerospace Sector (SIAS).

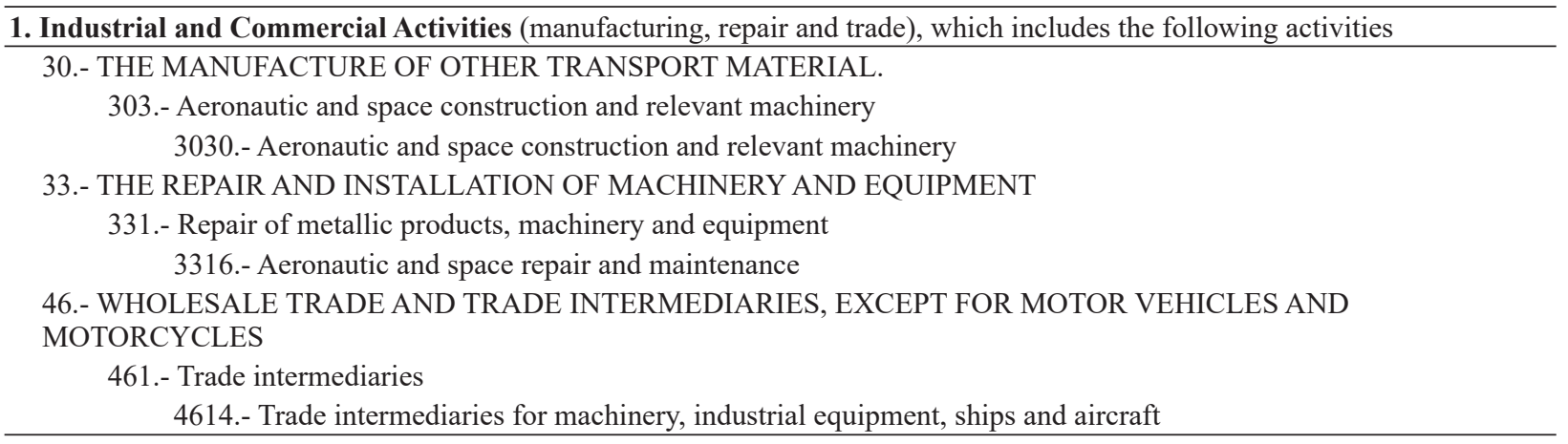

2. Service Activities (transport and education) consisting of the following activities:

\title{
51.- AIR TRANSPORT:
}

511.- Passenger air transport 5110.- Passenger air transport

512.- Air transport of goods and space transport 5121.- Air transport of goods

85.- EDUCATION including

855.- Other education 8553.- Driving and flying school activities

\author{
3. Leisure Activities that include \\ 93.- SPORTING, RECREATIONAL AND ENTERTAINMENT ACTIVITIES \\ 931.- Sporting activities \\ 9312.- Sports club activities
}


TABLE III

Absolute and relative values of risks in ACSOM-G, SIAS and SS.

\begin{tabular}{crrrrrr}
\hline RISK & ACSOM G & fr ACSOM G & SIAS & fr SIAS & \multicolumn{1}{c}{ SS } & fr SS \\
\hline R1 & 164876 & 0.06377 & 2931 & 0.04540 & 979 & 0.05392 \\
R2 & 216417 & 0.08370 & 4510 & 0.06986 & 1386 & 0.07633 \\
R3 & 100272 & 0.03878 & 1970 & 0.03051 & 481 & 0.02649 \\
R4 & 125423 & 0.04851 & 3256 & 0.05043 & 523 & 0.02880 \\
R5 & 73184 & 0.02831 & 1492 & 0.02311 & 292 & 0.01608 \\
R6 & 8920 & 0.00345 & 94 & 0.00146 & 23 & 0.00127 \\
R7 & 280689 & 0.10856 & 7759 & 0.12018 & 2320 & 0.12777 \\
R8 & 99825 & 0.03861 & 2880 & 0.04461 & 676 & 0.03723 \\
R9 & 168052 & 0.06500 & 3813 & 0.05906 & 441 & 0.02429 \\
R10 & 67890 & 0.02626 & 1238 & 0.01918 & 208 & 0.01146 \\
R11 & 50513 & 0.01954 & 1248 & 0.01933 & 457 & 0.02517 \\
R12 & 180538 & 0.06983 & 4719 & 0.07309 & 1580 & 0.08702 \\
R13 & 923718 & 0.35726 & 26017 & 0.40298 & 7888 & 0.43443 \\
R14 & 5211 & 0.00202 & 77 & 0.00119 & 32 & 0.00176 \\
R15 & 6460 & 0.00250 & 86 & 0.00133 & 16 & 0.00088 \\
R16 & 64424 & 0.02492 & 1116 & 0.01729 & 207 & 0.01140 \\
R17 & 1256 & 0.00049 & 263 & 0.00407 & 253 & 0.01393 \\
R18 & 4803 & 0.00186 & 75 & 0.00116 & 13 & 0.00072 \\
R19 & 43068 & 0.01666 & 1018 & 0.01577 & 382 & 0.02104 \\
TOTAL & 2585539 & 1.0000 & 64562 & 1.0000 & 18157 & 1.000 \\
\hline
\end{tabular}

\section{METHODS}

The ACSOM method was used, given its utility for the comprehensive processing of data related to accidents in the workplace based on the comparison of the sectors to be analysed with the reference pattern (García et al. 2007, Rubio et al. 2012). In this case, the relevant comparisons were SIAS vs ACSOM G and SS vs SIAS.

The BIOIN programme was used to process already-translated data, present results and to draft the phased planning report on the risks for which preventative action will be developed (Rubio et al. 2008a, b, 2012, Torner et al. 2008).

The General ACSOM (ACSOM G) or accident pattern for the entire Spanish working population during the period studied is represented by a descending polygonal line. The ordinate axis shows the frequency with which a certain risk causes an accident and the abscissa shows the risks ordered from lowest to highest frequency.
The corresponding polygonal line was also calculated for the SIAS, for comparison with ACSOM G. Subsequently, the SIAS was used as a pattern or ACSOM of the sector for comparison with the Services Subsector, for which the polygonal line was also calculated.

Comparison of the ACSOM pattern with the relevant sector or subsector allows analysis of the accident scenarios within the sector of interest. This is a dual comparison, given that it involves statistical comparison of proportions and comparison of the order of each series.

Haberman's adjusted residuals, which are generally referred to as Adjusted Residuals (AR), were used for the statistical comparison of proportions (although Freeman-Tukey's residual was used for risks whose expected frequency was less than 5). AR values higher or lower than +/-1.96 were considered significant deviations. Values greater than +1.96 and less than -1.96 are 
considered excess deviation and default deviation. Values lying between each of these limits are considered equal deviation.

The second comparison compared the order of the risks in each series. Risks were ordered from highest to the lowest in each series according to their frequency. Differences in the order of risks in the analysed sector with respect to that of the reference pattern are known as translocations (García et al. 2009). A positive number (number of steps forward) or a negative number (number of steps back) is assigned depending on how far up or down the series each risk moves relative to the ACSOM. Values greater than 1 are deemed advanced translocations and values less than -1 backward translocations. Values between +1 and -1 are termed equal translocations.

The ACSOM method generates a risk diagram, which consists of the polygonal line of the reference pattern (in the first case ACSOM G and in the second SIAS) and the polygonal line of that with which is to be compared (in the first case SIAS and in the second the Services Subsector). A second diagram that includes the calculated statistics (Deviations and Translocations) is also created. Each risk is assigned two columns in this diagram with the relevant values; the first column relates to translocations and the second to deviations.

Through the BIOIN programme, which combines both statistics, the ACSOM method produces reports that include the risks ordered by activity phases.

Initially, if we consider all possible combinations of both statistics, there can only be 9 phases.

The first phase includes the risks that perform worst result relative to the reference pattern: excess deviation and advanced translocation. These are ordered within each phase according to the corresponding deviation value. In the event of two or more identical deviation values risks are ordered based on the corresponding translocation. The final phase includes the risks that show the best results,
TABLE IV

Generation of Phases by BIOIN.

\begin{tabular}{ccc}
\hline DEVIATION & TRANSLOCATION & PHASES \\
\hline \multirow{3}{*}{ Excess } & Advanced & 1 \\
& Equal & 2 \\
& Backward & 3 \\
\hline \multirow{3}{*}{ Equal } & Advanced & 4 \\
& Equal & 5 \\
& Backward & 6 \\
\hline \multirow{2}{*}{ Defect } & Advanced & 7 \\
& Equal & 8 \\
& Backward & 9 \\
\hline
\end{tabular}

i.e., those that perform better than the pattern: defect deviation and backward translocation (Torner et al. 2008, García et al. 2009). If a given risk is placed first in the frequency order in both series, and the deviation value is significant (excess deviation), the programme considers this an advanced translocation and moves on to Phase 1 (Table IV).

The risks that perform the worst are considered "weaker". This weakness represents vulnerability, as these are risks whose prevention could be made more effective and efficient, given that the corresponding values are higher than those of the reference pattern in both comparisons (deviations and translocations). These risks are deemed Priority Action. Conversely, "stronger" risks are less vulnerable.

The severity of each risk is classified in accordance with the method described by Adesanya et al. (2014). Those authors used data mining methods, specifically Cart and CHAID classification trees, to classify severity at the national level based on the number of days leave associated with a given accident.

\section{RESULTS}

RESULTS OF THE ANALYSIS OF RISKS IN THE INDUSTRIAL AEROSPACE SECTOR (SIAS) AS COMPARED WITH THE ACSOM OF THE SPANISH WORKING POPULATION (ACSOM-G)

The SIAS vs ACSOM G comparison is shown in Figure 1, and the dual comparison between the two sectors in Figure 2. 


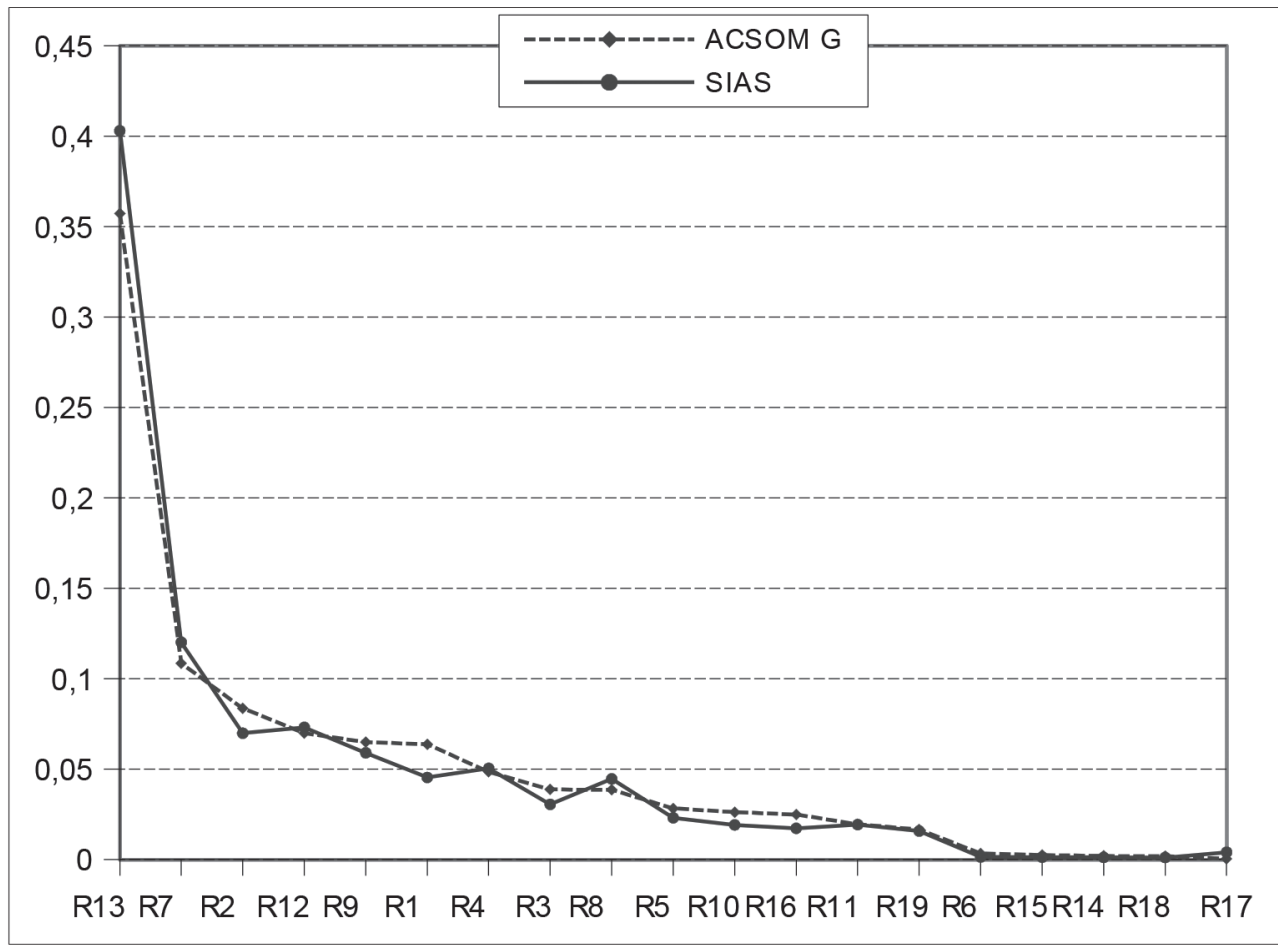

Figure 1 - SIAS vs ACSOM G Polygonal Lines.

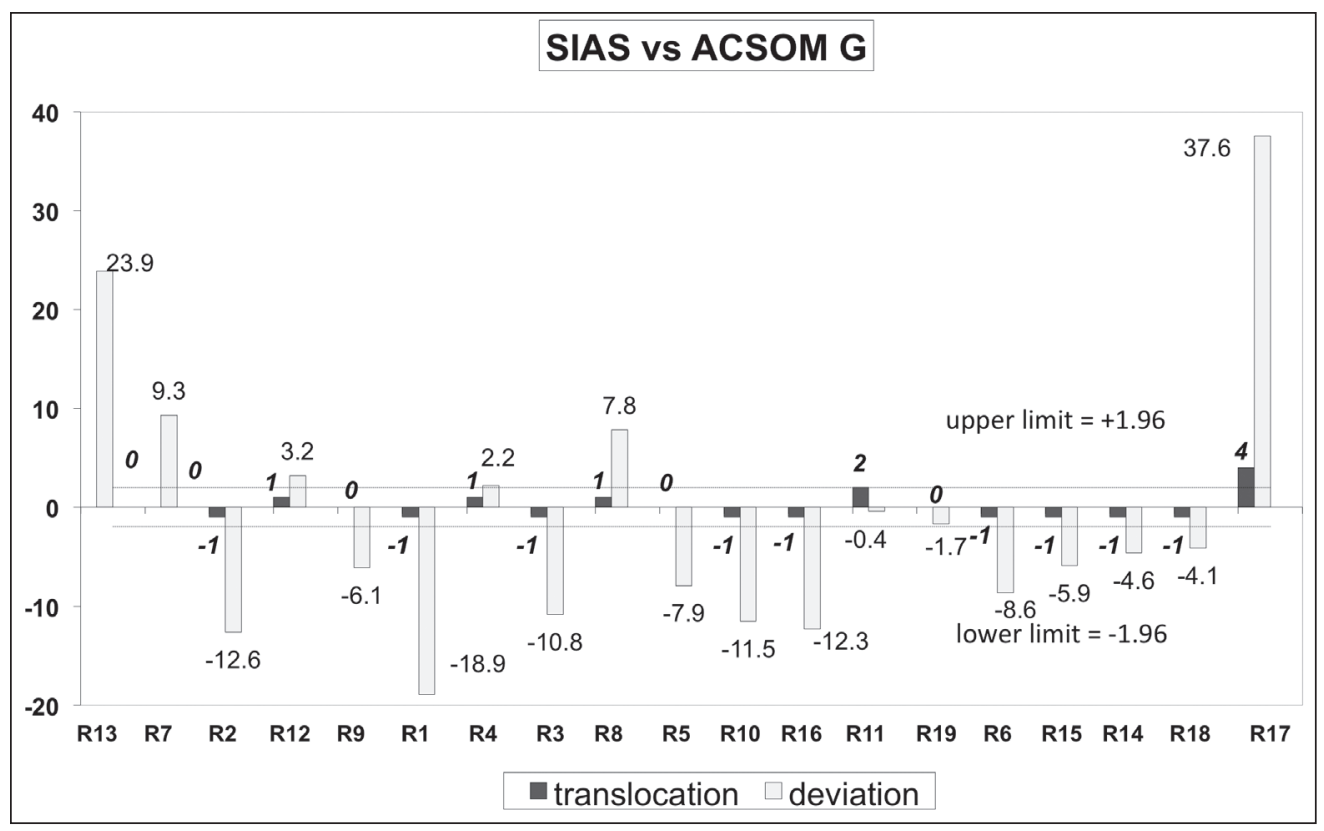

Figure 2 - SIAS vs ACSOM G Dual Comparison.

The highest deviation values (AR) were detected for $\mathrm{R} 17$ risks (Exposure to radiation) and R13 risks (Overstrain) (37.6 and 23.9, respectively). The following risks also showed significant positive deviations: R7 (Collision with stationary objects), 9.3; R8 (Collision with moving object), 7.8; R12 (Accidents involving mobile machinery and traffic), 3.321; and R4 (Falls of objects on 
persons by handling), 2.2. All other risks were non-significant or showed negative values (i.e., performed better than the ACSOM G).

For translocations, generally low values were observed in the second analysis, except in the case of R17 (Exposure to radiation), which showed a positive value of 4 units. R11 showed a positive value of 2 units. All other risks showed changes of $1(+/-1)$ unit, or retained their position.

$\mathrm{R} 13$ was the first risk in order of frequency, as also seen in the reference pattern. Accordingly, this risk showed no translocation and a significant AR, which led to the programme placing it in the first phase (as described in the Method).

Based on the aforementioned results, the BIOIN programme proposed a phased prioritisation (Table V).

RESULTS AND ANALYSIS OF RISKS IN THE SERVICE SUBSECTOR (SS) VERSUS THE SPANISH INDUSTRIAL AEROSPACE SECTOR (SIAS)

The Services Subsector vs. SIAS comparison is shown in Figure 3, and the dual comparison between the two sectors in Figure 4.

TABLE V

SIAS vs ACSOM Phases.

\begin{tabular}{cccl}
\hline DEVIATION & TRANSLOCATION & PHASES & \multicolumn{1}{c}{ RISKS } \\
\hline \multirow{2}{*}{ Excess } & Advanced & 1 & $\mathrm{R}_{17}, \mathrm{R}_{13}$ \\
& Equal & 2 & $\mathrm{R}_{7}, \mathrm{R}_{8}, \mathrm{R}_{12}, \mathrm{R}_{4}$ \\
& Backward & & \\
\hline \multirow{2}{*}{ Equal } & Advanced & 3 & $\mathrm{R}_{11}$ \\
& Equal & 4 & $\mathrm{R}_{19}$ \\
& Backward & & \\
\hline \multirow{2}{*}{ Defect } & Advanced & & \\
& Equal & & \\
& Backward & 5 & $\mathrm{R}_{18}, \mathrm{R}_{14}, \mathrm{R}_{15}, \mathrm{R}_{9}, \mathrm{R}_{5}, \mathrm{R}_{6}, \mathrm{R}_{3}, \mathrm{R}_{10}, \mathrm{R}_{16}, \mathrm{R}_{2}, \mathrm{R}_{1}$ \\
\hline
\end{tabular}

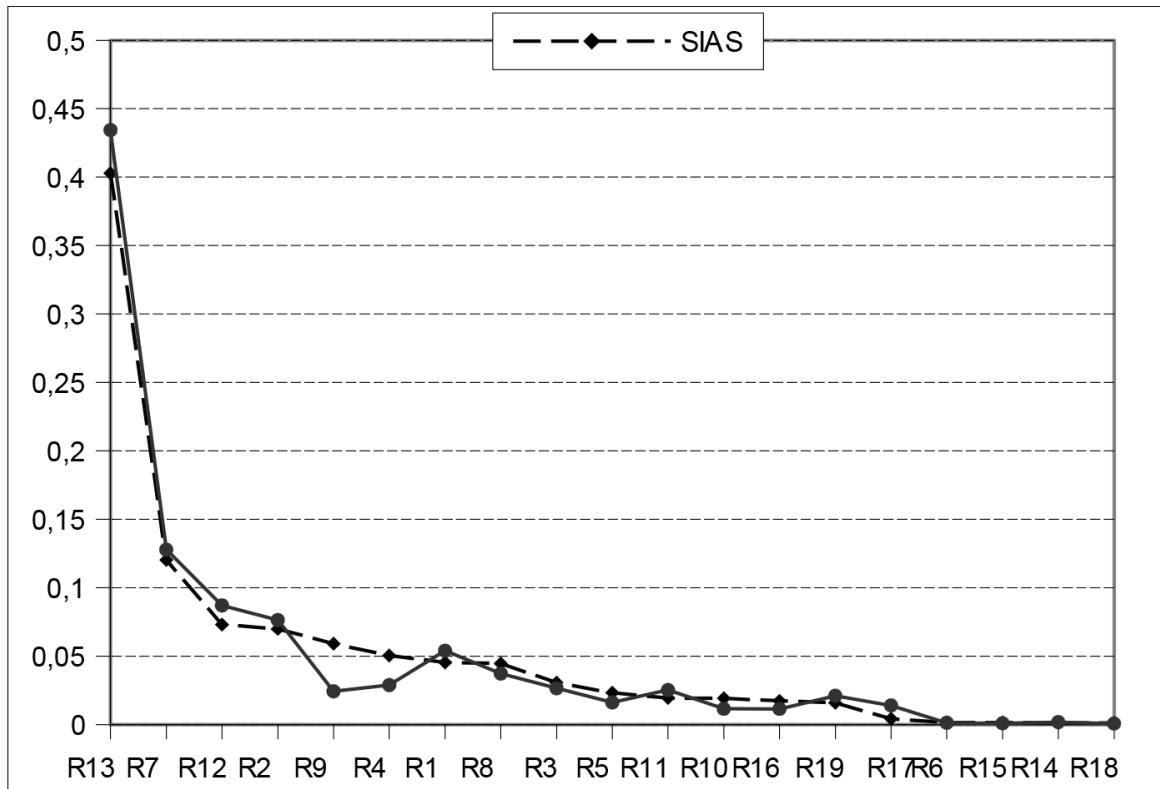

Figure 3 - Services Subsector (SS) vs SIAS Polygonal Lines. 


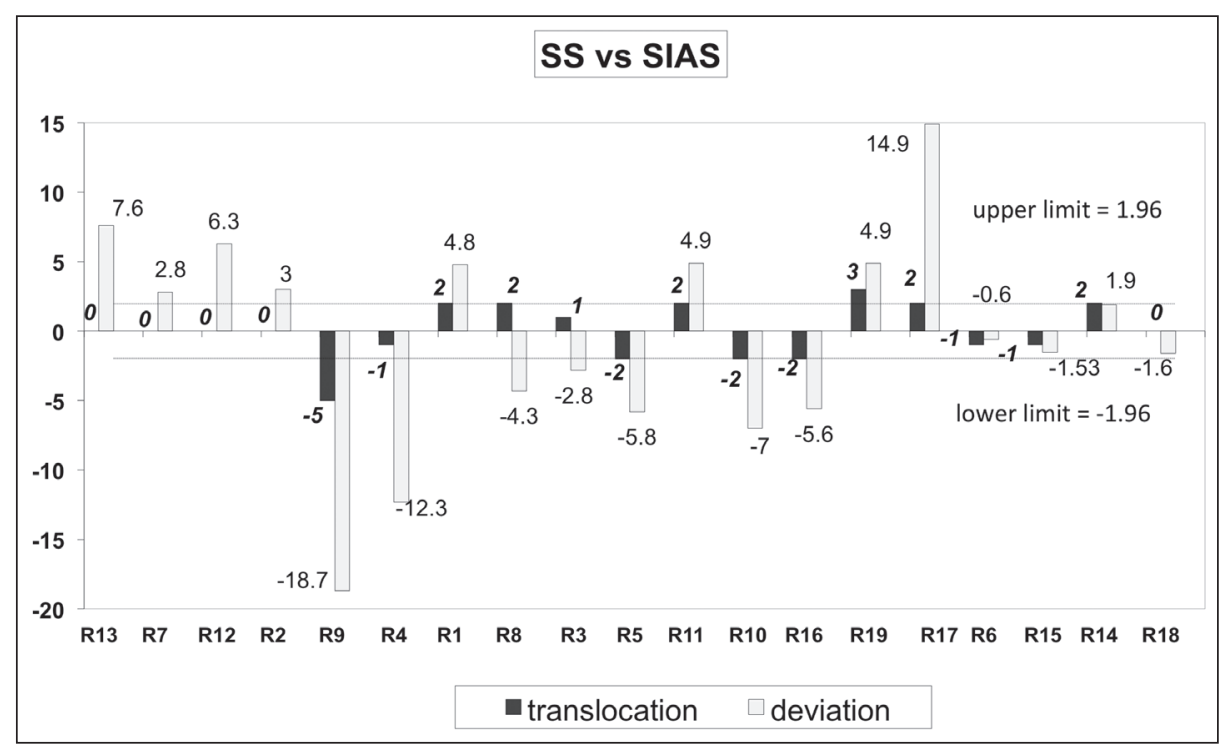

Figure 4 - Services Subsector (SS) vs SIAS Dual Comparison.

The highest deviation was observed for R17 (Exposure to radiation, 14.9), followed by R13 (Overstrain, 7.6); R12 (Accidents involving mobile machinery and traffic, 6.3); R11 (Entrapment by or between objects, 4.9); R19 (Accidents caused by living beings, 4.9); R1 (Falls of persons from a height (at different level), 4.8); R2 (Slips, trips, falls of persons (at one or same level), 3); and R7 (Collision with stationary objects, 2.8).

Regarding translocations, positive values (advanced) were observed for R19 (3 units), R1, R8, R11, R17, and R14 (2 units), and R3 (1 unit).

Based on these data, the BIOIN programme proposed another phased order (Table VI).

\section{DISCUSSION}

Our findings emphasise the importance of the risk posed by R17 (Radiation) within the workplace. This risk was very uncommon in the reference pattern (ACSOM G), and as reported by Adesanya et al. (2014), poses very little danger to the general population. However, in both SIAS and SS a significant increase was observed in R17 (Radiation) with respect to the reference pattern, resulting in the highest deviation value for SIAS (AR=37.6). It would be inconceivable that, given the high value of the contrast, this could pass unnoticed. Moreover, despite being a near-irrelevant risk in ACSOM G,

TABLE VI

Phases SS vs SIAS.

\begin{tabular}{cccl}
\hline DEVIATION & TRANSLOCATION & PHASES & \multicolumn{1}{c}{ RISKS } \\
\hline \multirow{3}{*}{ Excess } & Avanced & 1 & $\mathrm{R}_{17}, \mathrm{R}_{13}, \mathrm{R}_{19}, \mathrm{R}_{11}, \mathrm{R}_{1}$ \\
& Equal & 2 & $\mathrm{R}_{12}, \mathrm{R}_{2}, \mathrm{R}_{7}$ \\
& Backward & & \\
\hline \multirow{2}{*}{ Equal } & Avanced & 3 & $\mathrm{R}_{14}$ \\
& Equal & 4 & $\mathrm{R}_{6}, \mathrm{R}_{15}, \mathrm{R}_{18}$ \\
\hline \multirow{2}{*}{ Defect } & Backward & & \\
& Avanced & 5 & $\mathrm{R}_{8}$, \\
& Equal & 6 & $\mathrm{R}_{3}, \mathrm{R}_{4}$ \\
& Backward & 7 & $\mathrm{R}_{16}, \mathrm{R}_{5}, \mathrm{R}_{10}, \mathrm{R}_{9}$ \\
\hline
\end{tabular}


in SIAS R17 (Radiation) is found in the DELTA database declarations at a higher frequency than R6 (Treading on objects, piercing, cuts, etc.), R15 (Exposure to electrical contact), R14 (Exposure to thermal contact heat strain) and R18 (Explosions and fires). This observation is in line with the concern that those working in the aerospace sector, and in aircraft maintenance and passenger control, may be exposed to ionising radiation (essentially cosmic radiation and industrial $\mathrm{X}$ radiation) (Garcia and Gartman 1998, Patterson and Rayman 1998, Griffiths and Powell 2012).

The SS vs. SIAS comparison revealed a high deviation value for R17 (AR =14.9), which occurred at a higher frequency than R16 (Exposure to chemical substances) and R10 (Projections of fragments or particles), underscoring the importance of this risk in the Services Subsector.

Another significant risk is R13 (Overstrains), for which the second highest positive AR value was detected in both the SIAS vs. ACSOM G and SS vs. SIAS comparisons. This finding confirms the importance of R13 in aerospace activity (Gaona 2010); this risk was the most frequent in both sectors (SIAS and SS), as well as in ACSOM G. Moreover, the AR values for each "sector" with respect to the reference pattern were positive and significant. These results are in good agreement with the literature on "overstrain" (Briggs 1998). In the general population, the seriousness associated with R13 is moderate (Adesanya et al. 2014).

R19 (Accidents caused by living beings) was positioned third in terms of vulnerability, which Adesanya et al. (2014) also considers a moderate risk. Comparison of SS with SIAS revealed a translocation of 3 units and an AR of 4.9 for this risk, supporting the risk prevention measures against insects proposed by the WHO (WHO 2012). The influence of transport on the increase in infectious diseases was demonstrated by Gestal Otero (1997). Within the category of "Accidents caused by living beings" physical attacks by passengers on flight crews, mainly cabin staff, should also be considered (Rojas and Solano 2007).

Given that the importance of R17 was further highlighted in the SS vs. SIAS comparison, the following should borne in mind:

- The Services Subsector (SS) accounts for the significance of R17 in the SIAS.

- Given the difficulty in controlling exposure to ionising radiation in air transport, the "vulnerability" of this risk should be considered not as an indicator of the efficiency of controI, but rather an indication of the idiosyncrasy of the sector analysed.

- In this case, the "vulnerability" of a risk could be interpreted as the possibility of an increase in the incidence of the risk if the preventative pressure decreases, even slightly. In this sense, the maintenance of health and safety campaigns and monitoring of working conditions can help prevent increases in accident rates.

It should be emphasised that the BIOIN programme establishes a prioritisation of phases that represent the risk management recommendations made by ACSOM.

ACSOM limits itself to ordering risks from "worse" to "better" within the various action phases (without entering into technical considerations) and only provides information and guidelines to facilitate risk prevention.

It is the responsibility of health and safety officers to determine whether the "most vulnerable" risks should be subject to new actions or whether it is sufficient to continue with preventative pressure. In other words, health and safety officers should determine whether, at least in theory, all possible preventative actions are being or have been taken. If this is the case, a certification should be issued, and the next most vulnerable risk be examined.

Various conclusions can be drawn from the risk prevention point of view, depending on the level of the population with which the comparison is made. 
- From the comparison of SIAS with the general pattern (ACSOM G), general conclusions can be drawn for future health and safety campaigns. In this case, primary prevention policies can be considered, such as health and labour education within the area of prevention.

- From the comparison of the Services Subsector with the SIAS, general conclusions can be drawn that will be used for future prevention campaigns, which should be more specific and should include more precise objectives. Secondary prevention policies will also be considered, including prevention campaigns addressing specific risks aimed at both for workers and companies.

- Finally, tertiary prevention techniques should be applied in cases in which a given company is compared with the subsector within which its business activity is categorised. Specific preventive action is required for any vulnerable risks identified.

\section{CONCLUSIONS}

Our findings indicate that risks associated with radiation are significant in the industrial aerospace sector, in good agreement with empirical data from this sector. Moreover, our data show that the Services Subsector is the principal contributor to this outcome.

Overstrain was the most frequent risk in all three series analysed (ACSOM G, SIAS, and SS), and showed significant deviation values in both the SIAS vs. ACSOM G and SS vs. SIAS comparisons. As shown for radiation risks, this outcome can be attributed to the influence of the Services Subsector.

The risk of accidents caused by living beings is especially significant, given its high frequency in the Services Subsector. This risk was found to be specifically linked to the SS, rather than a feature of the overall sector (SIAS).
In summary, the ACSOM method has proved to be a valid tool for the analysis of risks in the workplace and in this particular sector, and allows for the prioritisation of the actions of health and safety officers. Given that our analysis focused on the SIAS and its SS (and not businesses), the preventative measures to be taken are primary and secondary prevention measures.

\section{REFERENCES}

ADESANYA V, GARCIA A AND RUBIO E. 2014. Métodos estadísticos en el análisis de la gravedad accidental laboral. Minería de datos. Algoritmos de árboles de clasificación. Editorial Academica Española. Saarbrücken.

BARRAGÁN JA. 2005. Historia del Sector aeronáutico (1) SEPI-Estrategias. Año IV, nº 16, May-Jun: 26-31.

BOURCIER D. 1998. Controles y Efectos sobre la Salud. Enciclopedia de Salud y Seguridad en el Trabajo. ILO. $3^{\mathrm{a}}$ SP Edition. Vol III, 90: 11-13.

BRIGGS DF. 1998. Seguridad y Ergonomía en la construcción aeronáutica. Enciclopedia de Salud y Seguridad en el Trabajo. ILO. $3^{\text {a }}$ SP Edition. Vol III, 90: 4-6.

BROCAL F. 2012. Riesgos laborales nuevos y emergentes en los procesos de fabricación. Técnica Industrial 297: 34-46.

CHIARA M ET AL. 2009. Quantitative analysis of ATM safety issues using retrospective accident data: the Dynamic Risk Modelling Project. Safety Sci 47(2): 250-264.

CONTE JC. 2004. Teoría del accidente en poblaciones laborales. Bases matemáticas. [Tesis Doctoral]. Zaragoza: Universidad de Zaragoza.

CONTE JC, GARCÍA AI AND RUBIO E. 2007a. Teoría del accidente en poblaciones. Cuad Bioestad Apl Inform 17: 36-38.

CONTE JC, MARCOS G, GARCÍA AI AND RUBIO E. 2007 b. Análisis del problema empírico de identificación del riesgo. Cuad Bioestad Apl Inform 17: 12-25.

CONTE JC AND RUBIO E. 2005. Estudio de la relación riesgo-lesión mediante análisis factorial. Real Acad Ciencias Zaragoza 60: 65-85.

CONTE JC AND RUBIO E. 2006. ACSOM y ProtoACSOM como indicadores centinelas. España. $\mathrm{N}^{\circ}$ registro: 02/2006/4314.

CONTE JC, RUBIO E AND GARCÍA AI. 2005. Teoría del accidente en poblaciones laborales.Bases matemáticas, aplicadas a las Situación RIESGO-LESION. España. N ${ }^{\circ}$ registro: 02/2005/5668.

CONTE JC, RUBIO E, GARCÍA AI AND CANO F. 2011 a. Correspondence model of occupational accidents. An Acad Bras Cienc 83: 1131-1146. 
CONTE JC, RUBIO E, GARCÍA AI AND CANO F. $2011 \mathrm{~b}$. Occupational accidents model based on risk-injury affinity groups. Safety Sci 49(2): 306-314.

FALCY M. 2010. Béryllium et composés. EMC (Elsevier Masson SAS, Paris), Pathologie professionnelle et de l'environnement, 16-002-B-10.

GAONA KL. 2010. Comparative study of musculoskeletal injuries in transport aircrew. Aviat Space Environ Med 81: 688-690.

GARCÍA AI, CONTE JC AND RUBIO E. 2007. Propuesta de un proceso automático para planificación en prevención de riesgos laborales. Cuad. Bioestad. Apl Inform 17: 39-49.

GARCÍA AI, CONTE JC, RUBIO E AND PEREZ A. 2009. Accidente laboral. ACSOM una nueva orientación para la gestión automática del riesgo. An Sist Sanit Navar 32 (1): 23-34

GARCIA N AND GARTMAN H. 1998. Operaciones de Vuelo de Aeronaves. Enciclopedia de Salud y Seguridad en el Trabajo. ILO. $3^{\text {a }}$ SP Edition. Vol III, 102: 14-18.

GAUMY M AND PROTEAU J. Protection des jeunes de moins de 18 ans et de la femme au travail. Encycl Med Chi, Paris, Intoxications, 16690A-10, 12-1982.

GESTAL OTERO JJ. 1997. Enfermedades infecciosas emergentes. Alerta mundial, respuesta mundial. Rev Esp Salud Publica No 3; 71: 225-229.

GRIFFITHS RF AND POWELL DMC. 2012. The occupational health and safety of flight attendants. Aviat Space Environ Med 83: 514-521.

INSHT. NTP-728: Exposición Laboral a radiación natural. Notas Técnicas de Prevención. Instituto Nacional de Seguridad e Higiene en el Trabajo. Ministerio de Trabajo y Asuntos Sociales España. http://insht.es/InshtWeb/Contenidos/ Documentacion/FichasTecnicas/NTP/Ficheros/701a750/ ntp_728.pdf

LEE WR. 1973. Emergence of occupational medicine in Victorian Times. Br J Ind Med 30(2): 118-124.

LYONS TJ AND NACE W. 2007. Aircraft crash rates and cumulative hours: USAF data for 25 airframes, 19502006. Aviat Space Environ Med 78: 923-925.

MELIA JL, RICARTE JJ AND ARNEDO MT. 1998. La Psicología de laseguridad: una revisión de los modelos procesualesde inspiración mecanicista. Rev de Psicol Gal y Aplic 51(1): 37-54.

NORMAND JC, MASSARDIER-PILONCHÉRY A, DE SURREL DE SAINT-JULIEN D AND DUCLOS JC. 2010.
Bruit. EMC (Elsevier Masson SAS, Paris), Pathologie professionnelle et de l'environnement, 16-502-A-10.

PATTERSON R AND RAYMAN RB. 1998. Medicina Aeroespacial: Efectos de la gravedad, la aceleración y la microgravedad en el entorno aeroespacial. Enciclopedia de Salud y Seguridad en el Trabajo. ILO. $3^{\text {a }}$ SP Edition 3(102): 18-22.

PELLET F. 2001. Matériaux composites. EMC-Pathologie professionnelle et del'environnement [Article 16-541-B30]: 1-11.

RAYMAN RB. 2006. Aircraft desinsection. Aviat Space Environ Med 77: 733-736.

ROJAS ML AND SOLANO M. 2007. Psicología y Aviación. Rev Reflexiones 86(2): 27-37.

RUBIO CALVO E, GARCÍA AI AND CONTE JC. 2012. ACSOM. Herramienta para el análisis de la accidentalidad laboral; y su programa BIOIN. Berlin. Editorial Academica Española.

RUBIO E, TORNER P, CONTE JC AND FELIPE AI. 2008a. Programa Bioin Omega I. Sistema traductor de base de datos en código Delta a códigos OIT. España. $\mathrm{N}^{\mathrm{o}}$ registro: 10/2008/305.2008.

RUBIO E, TORNER P, GARCIA AI AND CONTE JC. 2008b. Programa Bioin Omega, II. Análisis de la Variabilidad de perfiles para la planificación preventiva de riesgos y lesiones vulnerables. Método ACSOM. España. $\mathrm{N}^{\mathrm{o}}$ registro: 10/2008/306.

RUBIO GARCÍA B, GARCÍA AI AND DIAZ DE CERIO L. 2013. Búsqueda de un indicador dinámico de análisis de las complicaciones en Anestesiología y Reanimación: ANESTHSOM. Berlin. Editorial Academica Española.

SEIGNEURIC A. 1991. Pathologieliéeà 1>altitudeet aux vols dans l'atmosphère et dans l'espace. EMC - Pathologie professionnelle et del'environnement. [Article16506-A-10] pag. 1-10.

TORNER P, GARCÍA AI, CONTE JC AND RUBIO E. 2008. Programa Bioin Omega, III. Análisis de la Variabilidad de perfiles para la planificación preventiva de riesgos y lesiones vulnerables. Método ACSOM. España. N ${ }^{\circ}$ registro: 10/2008/487.

UTRILLA L. 2007. La aeronáutica española de 1898 a 1936. Urilla L. AENA. http://www.vilga.org/LTQ10/images/S23.4.Utrilla.pdf En 25SEP13.

WHO. 2012. International travel and health.Aircraft desinsectation. Geneva. Ed. WHO Health organization. 